\title{
High levels of genetic structure in the Australian freshwater fish, Ambassis macleayi
}

\author{
Joel A. Huey ${ }^{1}$ \\ Griffith University, Australian Rivers Institute, Griffith School of Environment, 170 Kessels Road, Nathan, \\ Queensland, Australia 4111 \\ Andrew M. Baker ${ }^{2}$ \\ Queensland University of Technology, School of Natural Resource Sciences, 2 George Street, Brisbane, \\ Queensland, Australia 4001 \\ Jane M. Hughes ${ }^{3}$ \\ Griffith University, Australian Rivers Institute, Griffith School of Environment, 170 Kessels Road, Nathan, \\ Queensland, Australia 4111
}

\begin{abstract}
The genetic structure of the freshwater fish Ambassis macleayi Castelnau 1878 was explored across the tropical catchments of the Gulf of Carpentaria Basin, northern Australia. The Gulf of Carpentaria provides a unique opportunity to explore simultaneously contemporary and historical gene flow resulting from unique climatic patterns and historical connectivity among catchments via a freshwater lake that existed during lower sea levels. The control region of the mtDNA genome and 4 microsatellite loci were used to detect significant genetic structure among and within catchments. Within catchments, genetic structure suggested that dispersal of $A$. macleayi is restricted, despite high levels of connectivity during summer monsoonal events. Among catchments, divergence appeared to be deeper than what would be predicted based on the last opportunity for connectivity via the lake of Carpentaria $(\sim 10,000$ years before present [ybp]). Overall, these results have important implications for A. macleayi and other members of this genus. If individuals are not proficient dispersers, recolonization after disturbance will be limited. Because of historical isolation among catchments, each catchment harbors unique genetic diversity that should be conserved independently.
\end{abstract}

Key words: gene flow, genetic structure, Lake Carpentaria, Ambassis macleayi, freshwater fish.

The long-term viability of a species is partly determined by its resilience to disturbance. This pattern is especially true for riverine species because populations inhabit highly variable environments that are subject to floods, droughts, glaciers, and human impacts (Lake 2003, Magoulick and Kobza 2003). For freshwater fish and other taxa unable to resist disturbance, dispersal among populations is a common strategy for maintaining population viability at the landscape scale (e.g., Labbe and Fausch 2000). This strategy maintains genetic diversity in populations, facilitates the spread of advantageous alleles, and allows species to recolonize extirpated regions

\footnotetext{
${ }^{1}$ E-mail addresses: j.huey@griffith.edu.au

2 am.baker@qut.edu.au

3 jane.hughes@griffith.edu.au
}

(Vrijenhoek 1998, Moran 2002). For freshwater fishes, one might expect populations to exchange high numbers of migrants, subsequently homogenizing gene frequencies and generating panmixia at large spatial scales (Huey et al. 2006, Hughes and Hillyer 2006, So et al. 2006). However, the opposite is often observed. Many species of freshwater fish exhibit strong to moderate genetic structure, indicative of restricted gene flow and limited dispersal among populations (Leclerc et al. 2008, Pereira et al. 2009).

Restricted gene flow is often observed in freshwater species because of the isolating nature of riverine systems (Ward et al. 1994, de Woody and Avise 2000, Hughes 2007). Within catchments, in-stream barriers to dispersal, such as waterfalls, dam walls, habitat heterogeneity, dried river reaches, and steep catchment gradients, act to restrict gene flow among 


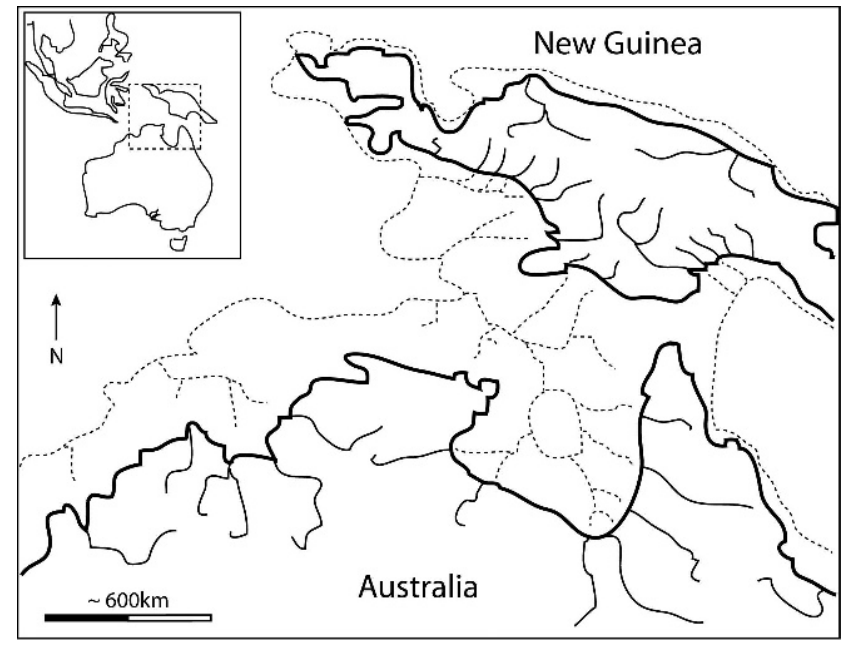

Fig. 1. Lake Carpentaria, Australia. The dark lines represent current coastline and rivers, and the dotted lines represent the -120 -m sea level contour with projected river channels (adapted from Voris 2000).

populations (Amoros and Bornette 2002). Among catchments, restricted gene flow is often caused by the inability of individuals to traverse catchment boundaries or to disperse through marine environments between the mouths of exorheic drainages (McGlashan and Hughes 2002, Masci et al. 2008).

Genetic structure among catchments often reflects predictions made under the Death Valley zoogeographic model, whereby populations are totally isolated (no migration) and, consequently, travel down unique evolutionary paths (Meffe and Vrijenhoek 1988). Populations in separate catchments often exhibit deep genetic divergences that reflect historical isolation. This pattern contrasts with genetic structure within catchments that often exhibits restricted gene flow caused by the dendritic nature of riverine systems (Meffe and Vrijenhoek 1988). Identifying the role of these isolating events in driving genetic divergence among populations is central to understanding the nature of within-species genetic variation and is valuable when managing wild fish populations (Meffe and Vrijenhoek 1988, Vrijenhoek 1998, Avise 2000).

Genetic structure among aquatic populations in Australia's Gulf of Carpentaria Basin has been studied for only a few species (Macaranas et al. 1995, McGuigan et al. 2000, de Bruyn et al. 2004, Baker et al. 2008, Huey et al. 2008, Masci et al. 2008), despite its obvious value for exploring the effects of landscape, historical, and biological processes on gene flow and genetic structure in wild populations of freshwater fish. Historically, catchments in the Gulf of Carpentaria Basin and the southern flowing catch- ments of Papua New Guinea were connected via Lake Carpentaria, a large inland lake that is now a marine gulf (Torgersen et al. 1983, 1988, Chivas et al. 2001) (Fig. 1). Chivas et al. (2001) suggested that this lake existed until $\sim 9700$ years before present (ybp), when rising sea levels inundated the lake and generated the conditions seen today in the Gulf of Carpentaria. Other estimates indicate that marine waters first entered Lake Carpentaria 12,200 and 10,800 ybp (Reeves et al. 2007, 2008). Many freshwater species have distributions across the Gulf of Carpentaria in both northern Australia and southern Papua New Guinea, a pattern suggesting that Lake Carpentaria historically was a conduit for gene flow for some species. The shift from a freshwater lake to a marine gulf is predicted to be a major driver of genetic structure among populations and has been invoked to explain genetic structure for some crustacean species in the region (de Bruyn et al. 2004, Baker et al. 2008).

One species found across this distribution, Ambassis macleayi Castelnau 1878 (Macleay's Glassfish), provides an ideal opportunity to explore the landscape and historical processes important in determining genetic structure in wild fish populations. Studies of this species from the Alligator River and aquarium observations suggest that most recruitment occurs during the dryer winter months (Kennard 1995, Pusey et al. 2004). During this dry period, most surface water is retained in isolated waterholes that become hydrologically connected during the wet monsoon period over summer (Perry 1964, Perry et al. 1964, Twidale 1964a, b). Because connectivity is lost in the dry season, new recruits have fewer opportunities to disperse to other populations, possibly leading to low migration among populations and divergence in gene frequencies.

The control region of mitochondrial deoxyribonucleic acid (mtDNA) and microsatellites were used to investigate the genetic structure of populations of A. macleayi among and within catchments in the Gulf of Carpentaria Basin. We predicted that populations of A. macleayi would exhibit significant genetic structure among populations within catchments (restricted gene flow) because of the breeding behavior of this species. We also predicted that populations of A. macleayi would be highly structured among catchments because of the isolation of catchments by the Gulf of Carpentaria $\sim 10,000$ ybp.

\section{Methods}

\section{Study area and sampling}

Sites were sampled across the Gulf of Carpentaria Basin during 2 trips (September 2004, August 2005). 


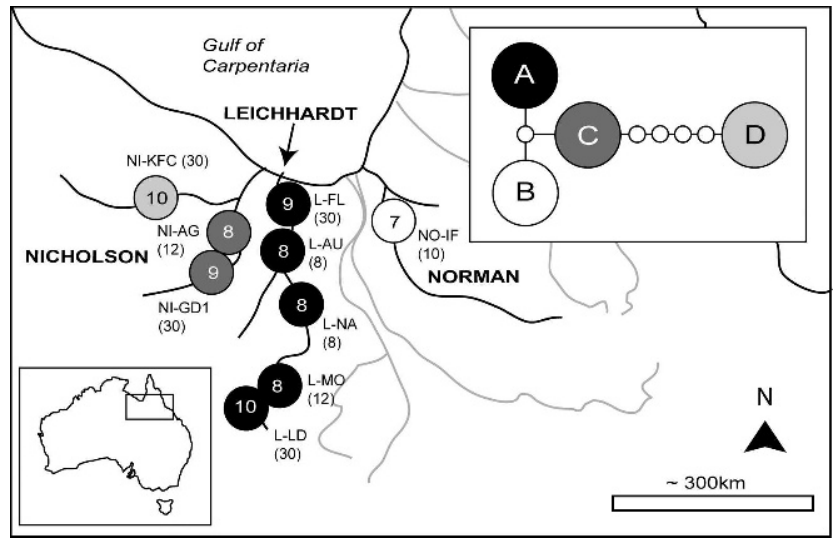

FIG. 2. Study area with sites and mitochondrial deoxyribonucleic acid (mtDNA) variation. Sites include codes (with prefix indicating catchment) and total sample sizes in brackets. Site codes are Kingfisher Camp (KFC), Adel's Grove (AG), Gregory Downs 1 (GD1), Floraville Station (FL), Augustus Downs Station (AS), Nardoo Station (NA), Lake Moondarra (MO), East Leichhardt Dam (LD), and Iffley Station (IF). The mtDNA network (inset to the upper right) is based on a 396-base pair fragment of the control region. Each haplotype is shaded to correspond with sites where it was sampled. The number of individuals sequenced from each site is found within each circle representing the site.

Thirty-four sites were sampled across 7 catchments, from the Mitchell River catchment in the east to the Nicholson River catchment in the west (Fig. 2). In all cases, fyke or seine nets were used to sample individuals from sites. Sampling continued until 30 individuals were caught or until extensive effort yielded no more individuals. Upon capture, individuals were fin clipped and released. Fin clips were bagged and immediately submerged in liquid $\mathrm{N}$ to preserve DNA and proteins for genetic analysis. Samples were stored in the laboratory at $-80^{\circ} \mathrm{C}$ (Forma Enviro-Scan Bio-Freezer, ThermoFisher Scientific, Waltham, Massachusetts) until used for genetic analysis. Ambassis macleayi is found in the same catchments as other, difficult-to-identify Ambassis species, so whole reference individuals were taken for confirmation by a resident fish biologist familiar with this species (M. Kennard, Griffith University).

\section{Laboratory methods}

Total genomic DNA was extracted from tissue using a modification of the cetyl trimethylammonium bromide $(\mathrm{CTAB}) /$ phenol-chloroform extraction procedure (Doyle and Doyle 1987). The final product was rehydrated in $100 \mu \mathrm{L}$ double-distilled $\mathrm{H}_{2} \mathrm{O}\left(\mathrm{ddH}_{2} \mathrm{O}\right)$ and stored at $4{ }^{\circ} \mathrm{C}$ until required for further analysis.
In up to 10 individuals from each sampled population, $\sim 400$ base pairs (bp) of the control region of the mtDNA genome were amplified using the PRO-L and MT-H primers (Palumbi et al. 1991). Twenty-five- $\mu \mathrm{L}$ polymerase chain reactions (PCRs) contained $17.2 \mu \mathrm{L}$ of $\mathrm{ddH}_{2} \mathrm{O}, 0.5 \mu \mathrm{L}$ of template DNA, $1.0 \mu \mathrm{L}$ of $10 \mathrm{mM}$ MT-H primer, $1.0 \mu \mathrm{L}$ of $10 \mathrm{mM}$ PRO-L primer, $0.5 \mu \mathrm{L}$ of $10 \mathrm{mM}$ deoxyribonucleotide triphosphate (dNTP) (Astral Scientific, Caringbah, Australia), $2.0 \mu \mathrm{L}$ of $25 \mathrm{mM} \mathrm{MgCl}_{2}$ (Astral Scientific), $2.5 \mu \mathrm{L}$ of $10 \times$ buffer (Astral Scientific), and $0.3 \mu \mathrm{L}$ of Thermus aquaticus DNA (Taq) polymerase (5 units $/ \mu \mathrm{L}$; Astral Scientific). Samples were subjected to the following PCR protocol: an initial hold of $95^{\circ} \mathrm{C}$ for $4 \mathrm{~min}$, followed by 40 cycles of $94^{\circ} \mathrm{C}$ for $30 \mathrm{~s}, 50^{\circ} \mathrm{C}$ for $30 \mathrm{~s}$, and $72^{\circ} \mathrm{C}$ for $60 \mathrm{~s}$. The reaction was followed by a final extension at $72^{\circ} \mathrm{C}$ for $5 \mathrm{~min}$ and a final hold at $4^{\circ} \mathrm{C}$.

PCR product was purified by adding $0.25 \mu \mathrm{L}$ exonuclease (Fermenta, Maharashtra, India) and $1.0 \mu \mathrm{L}$ shrimp alkaline phosphate $(1 \mathrm{unit} / \mu \mathrm{L}$; Promega, Madison, Wisconsin) to $5 \mu \mathrm{L}$ template DNA and was subjected to the following protocol: $37^{\circ} \mathrm{C}$ for $35 \mathrm{~min}$ followed by $80^{\circ} \mathrm{C}$ for $20 \mathrm{~min}$ and held at $4^{\circ} \mathrm{C}$ until required for the next step. The final product was then diluted, depending upon the strength of the original PCR product (typically 1:10). For the sequencing reaction, $2 \mu \mathrm{L}$ of terminator mix (BD version 3.1; Applied Biosystems, Scoresby, Australia), $2 \mu \mathrm{L}$ of $5 \times$ terminator mix buffer (Applied Biosystems), $0.32 \mu \mathrm{L}$ of $10 \mathrm{mM}$ PRO-L primer, $0.5 \mu \mathrm{L}$ of purified product, and $5.18 \mu \mathrm{L}$ of $\mathrm{ddH}_{2} \mathrm{O}$ were subjected to an initial hold of $96^{\circ} \mathrm{C}$ for $1 \mathrm{~min}$, followed by 30 cycles of $96^{\circ} \mathrm{C}$ for $10 \mathrm{~s}, 50^{\circ} \mathrm{C}$ for $5 \mathrm{~s}$, and $60^{\circ} \mathrm{C}$ for $4 \mathrm{~min}$. The reaction was then held at $4^{\circ} \mathrm{C}$ until required for further analysis. The final product was cleaned and then sequenced on an Applied Biosystems $3130 \times 1$ Genetic Analyser at the Griffith University DNA Sequencing Facility.

A microsatellite library was developed using the FIASCO method (Fast Isolation by AFLP of Sequences COntaining repeats; Zane et al. 2002) to identify polymorphic and informative microsatellite loci for $A$. macleayi. Four polymorphic loci were isolated successfully by the method outlined in Hillyer et al. (2007). Primers were developed (Table 1), and all sampled individuals were screened across all 4 loci. Microsatellite loci were amplified in $12.5-\mu \mathrm{L}$ PCR reactions containing $0.5 \mu \mathrm{L}$ of total genomic DNA extracted with the CTAB/phenol-chloroform method (described above), $0.5 \mu \mathrm{L}$ each of $10 \mathrm{mM}$ forward and reverse primers, $0.25 \mu \mathrm{L}$ of $10 \mathrm{mM}$ dNTPs, $1.0 \mu \mathrm{L}$ of $25 \mathrm{mM} \mathrm{MgCl}_{2}, 1.25 \mu \mathrm{L}$ of $10 \times$ buffer, $0.15 \mu \mathrm{L}$ of Taq polymerase ( 5 units $/ \mu \mathrm{L}$ ), and $8.35 \mu \mathrm{L}$ of $\mathrm{ddH}_{2} \mathrm{O}$. The reaction was subjected to an initial hold of $95^{\circ} \mathrm{C}$ for 
TABLE 1. Microsatellite loci developed and used in our study.

\begin{tabular}{llc}
\hline \hline Locus & \multicolumn{1}{c}{ Primer sequence $\left(5^{\prime}-3\right)$} & Microsatellite repeat motif \\
\hline AMB14 & F CCCGCAATTCACATGAGAAGC & $(\mathrm{CA})_{11}$ \\
& R CATGGCCAGATTGTCCTTACG & $(\mathrm{CA})_{9} \mathrm{AG}(\mathrm{CA})_{5}$ \\
AMB16 & F CTGCCTCTGTGGTGTTGAAGC & $(\mathrm{CA})_{12}$ \\
R GATCCATCCAGTCTGCCCTCG & F CTGCAGATCAAAGCGAGAACG & $(\mathrm{TG})_{12}$ \\
AMB22 & R GAAGAGGATGAAGGAATGCCG & \\
& F CAGAGAAAATCCTCAAATCCCC & \\
\hline
\end{tabular}

$5 \mathrm{~min}$, followed by 35 cycles of $95^{\circ} \mathrm{C}$ for $30 \mathrm{~s}, 50^{\circ} \mathrm{C}$ for $30 \mathrm{~s}$, and $72^{\circ} \mathrm{C}$ for $30 \mathrm{~s}$, with a final extension of $72^{\circ} \mathrm{C}$ for $5 \mathrm{~min}$. The product was then held at $4^{\circ} \mathrm{C}$ until subsequent analysis. Screening populations involved running denatured PCR product and GeneScan ${ }^{\mathrm{TM}} 350$ TAMRA $^{\mathrm{TM}}$ (Applied Biosystems, Scoresby, Australia) size marker through a 5\% denaturing acrylamide gel using a GelScan 2000× (Corbett Research, Sydney, Australia). A 1:1 PCR product:dye (5 mg of bromophenol blue, $50 \mathrm{~mL}$ of formamide, $100 \mu \mathrm{L}$ of $0.5 \mathrm{M}$ ethylenediaminetetraacetic acid [EDTA]) mixture was made and denatured by holding the product at $95^{\circ} \mathrm{C}$ for $5 \mathrm{~min}$ and then applying ice. This mixture was then run at $1200 \mathrm{~V}$ and scored by eye and with ONEDSCAN software (version 2.03; Scanalytics Inc., Rockville, Maryland). After identification of size, each sample was recorded for use in statistical analysis.

\section{Statistical analysis}

Mitochondrial sequences were aligned by eye and with SEQUENCHER (version 4.11; Gene Codes Corporation, Ann Arbor, Michigan). The gene diversity and nucleotide diversity at each site were calculated using ARLEQUIN (version 3.1; Excoffier et al. 2005). The evolutionary relationships between haplotypes were ascertained with TCS (version 1.21; Clement et al. 2000), with 95\% parsimoniously plausible branch connections between haplotypes.

For the microsatellite data set, sources of scoring and sampling error were investigated using MICROCHECKER (van Oosterhout et al. 2004). MICROCHECKER generates expected homozygote and heterozygote allele size frequencies and uses HardyWeinberg Equilibrium theory (HWE) to detect deviations from expectations (van Oosterhout et al. 2004). These deviations are then investigated and used as evidence for null alleles, stutter bands, and long allele dropout. Deviations from HWE were tested at each sampled population and locus with exact tests with 10,000 dememorization steps (ARLEQUIN) (Levene 1949, Guo and Thompson 1992). In conjunction with
HWE, $F_{\text {IS }}$ values were calculated using GENEPOP (Raymond and Rousset 1995). Average gene diversity across loci was calculated (ARLEQUIN).

Evidence for recent reductions in the effective population sizes of populations was sought in the microsatellite data set and analyzed with the program BOTTLENECK (Piry et al. 1999). BOTTLENECK uses the total number of alleles to estimate expected heterozygosity based upon 3 mutation models, the infinite alleles model (IAM), the 2-phase model (TPM), and the stepwise mutation model (SMM). Then, BOTTLENECK statistically tests the relationship between observed and expected heterozygosity using a Sign test, Wilcoxon sign-rank test, or a standardized differences test with each locus as a replicate (Piry et al. 1999). For our study, the Wilcoxon signrank test was used because it provides higher power than the other tests and requires as few as 4 polymorphic loci and 15 individuals (Cornuet and Luikart 1996, Piry et al. 1999). BOTTLENECK also uses a qualitative approach when identifying bottlenecks. Luikart et al. (1998) used simulations to show that the mode of the allele frequency distribution shifted if populations had recently (a few generations) experienced a population bottleneck. In our study, BOTTLENECK was used to calculate the allele frequency distribution and to identify mode shifts qualitatively.

Analysis of Molecular Variance (AMOVA) was used to partition the genetic variation hierarchically among catchments and among sites within catchments (ARLEQUIN). For the mtDNA data set, fixation values were calculated using $\Phi_{\mathrm{ST}}$, an $F_{\mathrm{ST}}$ analogue that uses sequence divergence among haplotypes when partitioning variation (Excoffier et al. 1992). For the microsatellite data set, the $F_{\mathrm{ST}}$ analogue $\theta$ was used (Weir and Cockerham 1984). For the microsatellite data set, locus-by-locus AMOVAs also were done. Pairwise $F_{\mathrm{ST}}$ tables were calculated for both markers (ARLEQUIN).

For both genetic markers, Mantel tests were calculated to test for significant relationships between geographic and genetic distances (ARLEQUIN). A 
significant correlation between geographic and genetic distance can be suggestive of isolation by distance, whereby adjacent populations exchange more migrants than distant populations (Wright 1943). In all cases, Slatkin's Linearized $F_{\mathrm{ST}}$ (ARLEQUIN) was used $\left(F_{\mathrm{ST}} /\left[1-F_{\mathrm{ST}}\right]\right)$ (Slatkin 1995). These tests were done across the entire sampling area and in each catchment individually. Mantel tests were calculated separately for stream distance and overland distance (derived using Google Earth ${ }^{\mathrm{TM}}$ ) in an attempt to identify the relative importance of floodplain vs channel movement. Stream distances between catchments in the Gulf of Carpentaria Basin were calculated via the Gulf of Carpentaria (along the present-day coastline).

The program IM (Hey and Nielsen 2004) was used to estimate the time since divergence between populations in different catchments. IM uses Bayesian techniques and Markov Chain Monte Carlo (MCMC) algorithms to estimate simultaneously the constant effective population sizes for 2 populations $\left(\theta_{1}, \theta_{2}\right)$, the ancestral constant effective population size prior to the population split $\left(\theta_{\mathrm{A}}\right)$, gene flow rates per gene copy per generation $\left(\mathrm{m}_{1}, \mathrm{~m}_{2}\right)$, and the number of generations ago that the populations split $(t)$ as a function of the mutation rate $(\mu)$. Contemporary migration among catchments is unlikely because of the marine Gulf of Carpentaria, so it was assumed that the migration rate between catchments would be 0 . Prior distributions for the parameters were specific to each pairwise comparison, and multiple runs of each comparison were made to ensure that the best estimate of divergence was obtained. For each comparison, 10 million steps were used in the chain with a burn-in of 100,000 steps. Once the posterior distribution was obtained, the bin that yielded the highest residence time was used as the point estimate. An estimate of credibility was obtained by taking the $95 \%$ intervals from the posterior distribution.

Only mtDNA was used for the IM analysis because estimates of all parameters are scaled by mutation rate, which is unknown for microsatellite loci. To convert the estimate of mutational time since population divergence $(t)$ to years $(t)$, we applied the equation used in Hey and Nielsen (2004), $t=\mathrm{t} \mu$ (or, $\mathrm{t}$ $=t / \mu)$, where $\mu$ is the number of mutations per locus per generation. The mutation rate was derived from a divergence rate of $3.6 \%$ per million generations (Donaldson and Wilson 1999). Members of the genus Ambassis become sexually mature in $1 \mathrm{y}$ (Pusey et al. 2004), so estimates of generations since population divergence were converted to years since population divergence.

\section{Results}

Sampling of A. macleayi across the Gulf of Carpentaria Basin yielded 140 individuals, taken from 9 populations and 3 catchments (Nicholson, $n=72$; Leichhardt, $n=88$; Norman, $n=10$ ) (Fig. 2). Unfortunately, A. macleayi was not captured in the Flinders, Gilbert, Staaten, and Mitchell catchments. Using SEQUENCHER, 396-bp fragment of the mtDNA control region was aligned and was used for further analysis (no indels were detected). Screening of the control region revealed only 4 haplotypes (Genbank Accession numbers: GU201600-GU201603, haplotypes A-D), each restricted to a single drainage (Fig. 2). Each site contained only a single haplotype, so haplotype and nucleotide diversity were 0 for each population. The evolutionary relationship between haplotypes suggested that 3 of the 4 haplotypes were all $1 \mathrm{bp}$

TABLE 2. Gene diversity and $F_{\mathrm{IS}}$ at each locus, across populations, based on microsatellites. For $F_{\mathrm{IS}}$ values, * indicates that the population significantly deviates from Hardy-Weinberg equilibrium (HWE) at that locus $(p<0.05)$ and mono indicates that the locus was monomorphic in that population.

\begin{tabular}{|c|c|c|c|c|c|c|}
\hline \multirow[b]{2}{*}{ Catchment } & \multirow[b]{2}{*}{ Site } & \multicolumn{5}{|c|}{ Microsatellites } \\
\hline & & Gene diversity & AMB14 & AMB16 & AMB21 & AMB22 \\
\hline \multirow[t]{3}{*}{ Nicholson } & GD1 & 0.52 & 0.21 & -0.04 & 0.02 & -0.14 \\
\hline & $\mathrm{AG}$ & 0.57 & 0.10 & Mono & $0.44^{*}$ & -0.04 \\
\hline & KFC & 0.42 & -0.10 & Mono & -0.09 & $0.34^{*}$ \\
\hline & $\mathrm{AU}$ & 0.46 & 0.05 & -0.17 & -0.08 & -0.03 \\
\hline & FL & 0.53 & 0.14 & -0.02 & 0.25 & 0.11 \\
\hline & NA & 0.58 & 0.08 & -0.40 & -0.06 & -0.02 \\
\hline Norman & IF & 0.57 & 0.64 & 0.18 & -0.30 & $-0.06^{*}$ \\
\hline
\end{tabular}


TABLE 3. Results from Analysis of Molecular Variance. Fixation indices that significantly deviate from 0 are marked. KFC $=$ Kingfisher Camp site on the Nicholson River. ${ }^{*}=p<0.05,{ }^{* *}=p<0.01$.

\begin{tabular}{|c|c|c|c|c|}
\hline Source & \multicolumn{2}{|c|}{ Control region } & \multicolumn{2}{|c|}{ Microsatellites } \\
\hline Among all catchments & 51.14 & $0.51^{*}$ & 14.08 & $0.14^{* *}$ \\
\hline Within populations & 0.00 & $1.00^{* *}$ & 69.90 & $0.30^{* *}$ \\
\hline Among populations within the Leichhardt catchment & & - & & $0.13^{* *}$ \\
\hline Among all catchments (no KFC) & 100.00 & $1.00^{* *}$ & 20.78 & $0.21^{* *}$ \\
\hline
\end{tabular}

divergent from an extinct or unsampled haplotype (Fig. 2 inset). The haplotype from 1 site (Kingfisher Camp [KFC]) on the Nicholson River was $5 \mathrm{bp}$ divergent from the closest extant haplotype.

Screening of microsatellite loci revealed $7,5,14$, and 15 alleles across all populations at loci AMB14, 16, 21, and 22, respectively. MICRO-CHECKER identified some evidence for null alleles ( 3 of 36 tests; data not shown). Four of the tests for HWE revealed populations that deviated significantly from HWE at a locus (Table 2). Three of these populations suffered from heterozygote deficiency (AG at AMB21, KFC at AMB22, and LD at AMB14). Population IF suffered from heterozygote excess at locus AMB22. Microsatellite gene diversity ranged from 0.22 to 0.58 . Microsatellite data revealed no quantitative evidence for a recent population bottleneck (data not shown). The mode of the allele distribution for 1 population, FL, was shifted.

AMOVA was done on 2 separate data sets. The first included site KFC in the Nicholson catchment, which was divergent at the mtDNA control region. The second excluded that site (Table 3). Both mtDNA and microsatellite loci showed significant genetic structure among catchments (mtDNA $\Phi_{\mathrm{CT}}=0.51$, microsatellite $F_{\mathrm{CT}}=0.14$ ). Both markers also showed genetic structure among populations within catchments $\left(\right.$ mtDNA $\Phi_{\mathrm{SC}}=1.00$, microsatellite $\left.F_{\mathrm{SC}}=0.19\right)$. mtDNA did not show genetic structure among or within catchments when site KFC was removed from the data set $\left(\mathrm{mtDNA} \Phi_{\mathrm{SC}}=0.00\right)$, but microsatellites showed significant genetic structure among populations within catchments even after site KFC was removed from the data set $\left(F_{\mathrm{ST}}=0.11\right)$. All microsatellite loci had similar $F_{\mathrm{ST}}$ values at each hierarchical level (locus-by-locus AMOVA; Table 4). Pairwise $F_{\mathrm{ST}}$ tests based on microsatellite loci were significant for 33 of 36 comparisons (Table 5).

Mantel tests were not done on mtDNA data because of the extremely low levels of diversity. Only 2 significant correlations were found in the microsatellite data set. Genetic and geographic distance (stream and overland distances) were highly positively correlated among all sites (stream distance: $r=$ $0.65, p=0.004$; overland distance: $r=0.61, p<0.001$ ). Neither stream nor overland distance were correlated with genetic distance within the Leichhardt catchment (stream distance: $r=0.52, p=0.089$; overland distance: $r=0.58, p=0.091$ ) (Fig. 3).

Control region mtDNA was used to calculate point estimates of the time since population divergence, $t$, for each pairwise comparison between catchments.

TABLE 4. Results from locus-by-locus Analysis of Molecular Variance. Fixation indices that deviate significantly from 0 are marked. KFC $=$ Kingfisher Camp site on the Nicholson River. ${ }^{*}=p<0.05,{ }^{* *}=p<0.01$

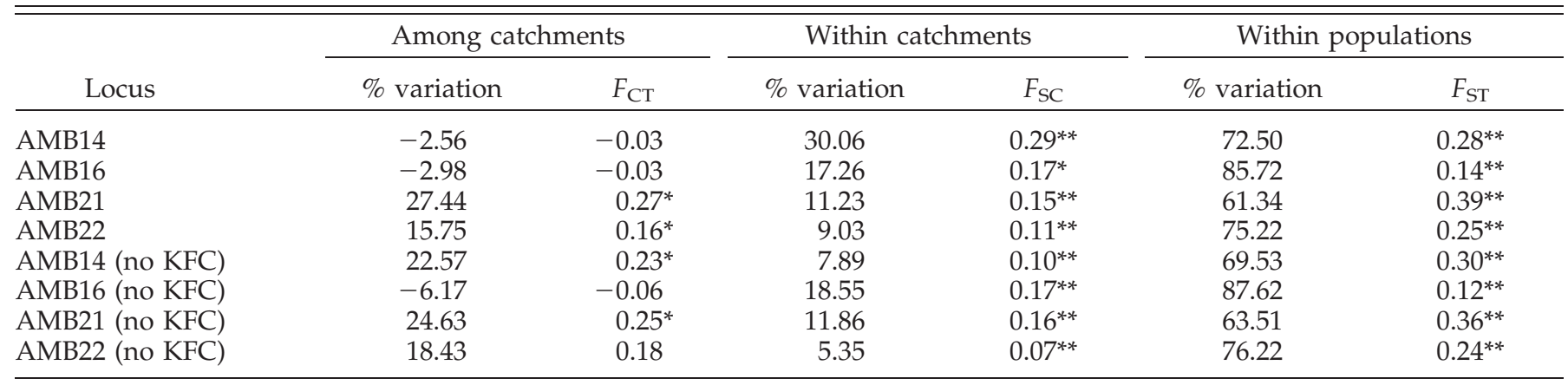


TABLE 5. Pairwise $F_{\mathrm{ST}}$ values based on microsatellite data. Fixation indices that deviate significantly from 0 are marked. ${ }^{*}=p<$ 0.05. See Fig. 1 for site codes and locations.

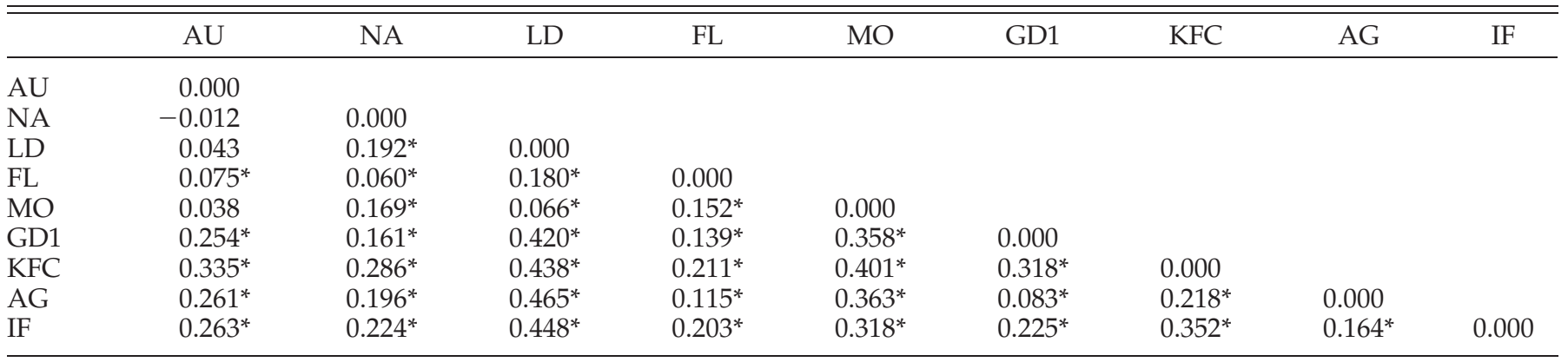

The Nicholson catchment was divided into 2 subcatchments, the Nicholson River proper (represented by site KFC) and the Gregory River (represented by sites AG and GD1). This action generated 6 pairwise combinations (Table 6) and revealed 2 groups of estimates. Estimates for the group that included the Nicholson River ranged from 266.5 to 378.8 thousand $y b p$, and estimates for the other group ranged from 109.4 to 120.6 thousand ybp.

\section{Discussion}

\section{Genetic diversity}

Four of the 36 tests for HWE deviated significantly from expectations. Significant tests were not consistent across loci or populations, and MICRO-CHECKER showed limited evidence for null alleles or misscored data. Therefore, it is unlikely that deviations from HWE were the product of selection, population specific processes (e.g., the Wahlund effect), poor gel scoring, or PCR-based errors. Control-region variation was extremely low, and a single haplotype was fixed at each site. In addition, a single haplotype was fixed at all sites in the Leichhardt catchment. This result is unusual for the control region, with other studies typically revealing higher genetic variation at this region (Stepien and Faber 1998, Hughes et al. 1999, Krieg et al. 2000, Ikeda et al. 2003, Takagi et al. 2006, Huey et al. 2008).

Low genetic diversity can be caused by selection or population processes, such as historical bottlenecks and low effective population size (Nei et al. 1975). The control region of the mtDNA genome is noncoding, so it is assumed to be free of selective constraint (Ballard and Kreitman 1995, Ballard and Dean 2001). However, because the mtDNA genome is not subjected to

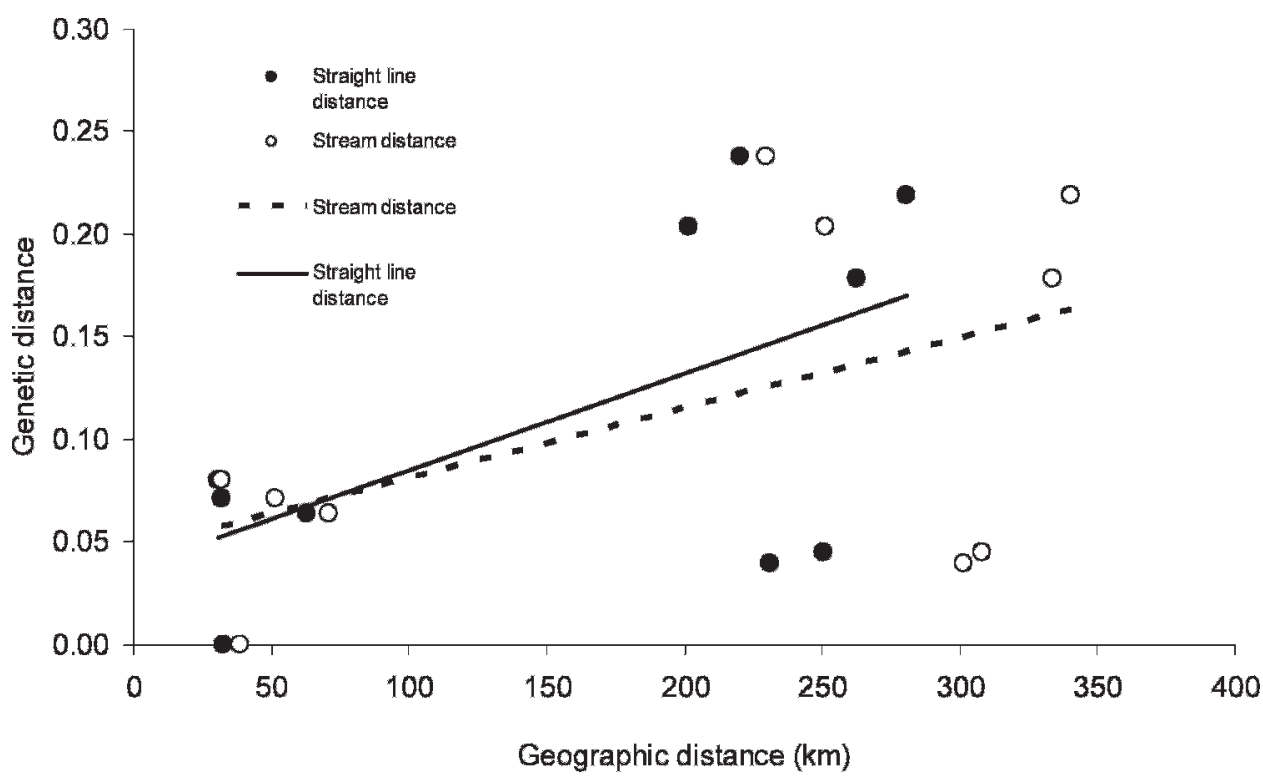

FIG. 3. Scatterplot correlating genetic distance (Slatkin's Linearized $F_{\mathrm{ST}}$ ) and geographic distance $(\mathrm{km})$ using stream and straight-line distances within the Leichhardt catchment. Lines represent the line of best fit through the data points. 
TABle 6. Results of IM analysis (Hey and Nielsen 2004) showing the maximum likelihood point estimate (MLE) of the time since population divergence $(\mathrm{t})$ and the $95 \%$ credibility intervals (CI).

\begin{tabular}{lccc}
\hline \hline \multicolumn{1}{c}{ Comparison } & MLE t & 0.025 CI & 0.975 CI \\
\hline Nicholson vs Gregory & 361,953 & 70,146 & 934,343 \\
Nicholson vs Leichhardt & 378,788 & 70,146 & 934,343 \\
Nicolson vs Norman & 266,554 & 53,311 & 765,993 \\
Gregory vs Leichhardt & 109,428 & 30,864 & 485,410 \\
Gregory vs Norman & 115,039 & 30,864 & 491,021 \\
Leichhardt vs Norman & 120,651 & 30,864 & 491,021 \\
\hline
\end{tabular}

recombination, selection on genes elsewhere on the genome will affect all other genes. This process, known as genetic hitchhiking (Maynard Smith and Haigh 1974), might explain the observed low diversity in the mtDNA data set. Unfortunately, neutrality tests, which can identify selection and bottlenecks in the mtDNA data set (Tajima 1989a, b, Fu 1997), were not done because of a lack of diversity within sites. Therefore, it is difficult to say whether selection can explain the low diversity in the mtDNA data set.

Population bottlenecks typically affect most loci across the genome, and therefore, can be verified by investigating different loci (Piry et al. 1999). Microsatellite loci revealed no substantial evidence for a population bottleneck, a result suggesting that a sudden reduction in population size does not explain the low variation at the control region of the mtDNA genome. However, the program BOTTLENECK suffers from low power when few loci are used (Cornuet and Luikart 1996, Luikart and Cornuet 1998).

\section{Gene flow and genetic structure within catchments}

Unfortunately, multiple sites within catchments were obtained only for the Leichhardt (5 sites) and Nicholson (3 sites) catchments. Nevertheless, significant genetic structure among populations within catchments was detected with microsatellite loci $\left(F_{\mathrm{SC}}\right.$ $=0.19)$. Furthermore, this pattern was retained after removing the highly divergent KFC site in the Nicholson catchment $\left(F_{\mathrm{SC}}=0.11\right)$. This pattern was not caused by data from only a few sites; 7 of 10 pairwise $F_{\mathrm{ST}}$ values in the Leichhardt catchment (the only catchment with adequate spatial sampling) were significant. This result indicates that gene flow among populations of $A$. macleayi is restricted within the Leichhardt catchment, despite monsoonal events that cause widespread flooding and hydrological connectivity across this catchment.

The breeding behavior of $A$. macleayi is a likely explanation for low levels of gene flow among populations within catchments. Studies of $A$. macleayi suggest that most recruitment occurs in the dry winter months (Kennard 1995, Pusey et al. 2004) when hydrological inputs are minimal and individuals residing in disconnected refugia would be unable to move between adjacent populations. Therefore, populations would be isolated when population sizes were at their maximum (i.e., post-spawning). When connectivity returned, populations would have decreased in size because of mortality in the new generation. Low levels of gene flow among populations within catchments also contradicts the suggestion that $A$. macleayi migrates upstream during the early wet season in response to changes in habitat availability (Bishop et al. 1995) because migration of this nature would reduce genetic divergence among populations.

Our suggestion that breeding behavior, rather than physical barriers, is responsible for restricting gene flow among populations in A. macleayi is supported by studies of other Australian freshwater fishes that have different breeding strategies. For example, low levels of genetic structure have been observed among populations within catchments in studies of Neosilurus hyrtlii, Porochilus argenteus, and Nematalosa erebi in the Lake Eyre Basin (Huey et al. 2006, 2008, Hughes and Hillyer 2006). For these species, peak spawning occurs during the wet summer months, thereby increasing the likelihood that recruitment will occur during periods of summer flow and high connectivity.

If populations of $A$. macleayi adhere to the steppingstone model of genetic structure, our detection of restricted gene flow among subpopulations suggests that adjacent subpopulations should be more genetically similar than distant subpopulations (isolation by distance; Wright 1943). Mantel tests correlating genetic and geographic distance within the Leichhardt catchment were not significant and did not support this hypothesis. Despite the nonsignificant Mantel test results, the scatterplot comparing genetic and geographic distance suggests some weak evidence for an isolation by distance effect. If populations remain in migration-drift equilibrium, populations might soon exhibit a significant correlation between genetic and geographic distance. Migration-drift equilibrium is attained when the antagonistic forces of genetic drift and gene flow are maintained at steady rates for an extended period of time and strike a balance whereby $F_{\mathrm{ST}}$ does not increase with time (Boileau et al. 1992, Slatkin 1993, Efremov 2004).

Closer inspection of the scatterplot correlating genetic and geographic distance in the Leichhardt 
catchment (Fig. 3) revealed another possible explanation for the lack of evidence for isolation by distance. Three pairwise comparisons (Augustus Downs [AU] with Moondarra Dam [MO], East Leichhardt Dam [LD], and Nardoo [NA]) had much less genetic divergence than predicted by the line of best fit through the scatterplot. The population from AD might be the product of a recent colonization event and might not be in migration-drift equilibrium with other populations in the catchment. As such, the AD population would not be expected to exhibit isolation by distance. Instead, pairwise comparisons would show less divergence than expected, as observed in our data set. Reanalysis with this population removed was not pursued because only 4 populations would have remained in the data set.

\section{Historical connectivity among catchments}

Excluding the highly divergent site at KFC in the Nicholson catchment, populations in catchments in the Gulf of Carpentaria were each fixed for a single unique haplotype, with 2 bp separating each haplotype. The lack of shared haplotypes among populations in separate catchments indicates allopatric fragmentation and total isolation among catchments because even low levels of gene flow would cause some sharing of haplotypes. Furthermore, the lack of shared haplotypes suggests an old vicariant event because genetic drift has had time to remove shared haplotypes from populations. Microsatellite data supported this finding and revealed significant structure among catchments (all sites: $F_{\mathrm{CT}}=0.14$, KFC removed: $F_{\mathrm{CT}}=0.21$ ).

Overall, the phylogeographic history of this locus appears to be simple. Each haplotype is found in a single catchment without evidence for long distance colonizations, range expansions, and other complex historical events. This result contrasts markedly with the findings of Cook and Hughes (2010), in which a complex gene tree for a freshwater species across northern Australia suggests a complex phylogeographic history dominated by combinations of longdistance dispersal, historical retention of haplotypes, vicariance, and range expansions.

Pairwise estimates of time since population divergence could be split into 2 groups, those involving the divergent population in the Nicholson River (KFC), and the rest. Point estimates between the Nicholson River and the rest of the Gulf of Carpentaria Basin ranged from 266 to 378 thousand ybp. Other point estimates ranged from 109 to 120 thousand ybp. The 95\% credibility intervals were all older than the predicted time that Lake Carpentaria became saline, $\sim 10$ thousand ybp (Chivas et al. 2001, Reeves et al. 2007, 2008). Therefore, populations of A. macleayi in each catchment probably became isolated much earlier, possibly because of a different historical event.

The observation of highly restricted gene flow among populations within catchments provides a possible explanation for the disparity between estimates of time since divergence among catchments and the estimate for the most recent connectivity event when Lake Carpentaria was fresh. Because populations of $A$. macleayi currently exhibit high genetic structure among populations within catchments, it is likely that populations in separate catchments had already begun to diverge when Lake Carpentaria was fresh. For this species, Lake Carpentaria was rarely used as a conduit for gene flow among catchments, despite available hydrological connectivity. The distribution of this species, from northern Australia to the trans-Fly region of Papua New Guinea (Pusey et al. 2004), indicates that perhaps Lake Carpentaria was responsible for rare dispersal events, although probably much longer than 10,000 ybp.

Another explanation for the disparity between estimates of time since divergence among catchments and the estimate for the most recent connectivity event is the appropriateness of the mutation rate used to calibrate the estimate. Some authors have suggested that using rates derived from interspecific divergence to calibrate estimates for intraspecific divergence might be inappropriate (Ho et al. 2005, Ho and Larson 2006; but see Emerson 2007). For example, estimates of the divergence rate of the control region based on recently diverged populations are much higher than the rates used in our study $(23.3 \%$ / million y, Burridge et al. 2006 vs 3.2\%/million y, Donaldson and Wilson 1999). If the faster rate were used, estimates of time since population divergence might overlap with the estimate for the most recent connectivity among catchments via the Lake of Carpentaria.

The divergence between the Kingfisher Camp site and the rest of the Nicholson catchment clearly is large considering that these sites are all found within a single contemporary, hydrologically connected catchment. It is important to note that the population at this site was declared highly divergent based on microsatellite loci (pairwise $F_{\mathrm{ST}}$ : range $=0.211-0.438$, mean $=0.320$ ). Thus, this divergence probably is not an anomaly unique to the mtDNA data set. Drainage rearrangements frequently are invoked to explain higher levels of divergence among fish populations within catchments than among catchments (McGlashan and Hughes 2000, 2001, Waters and Wallis 2000, 
Poissant et al. 2005). Drainage rearrangements can be caused by river capture when a river steals the headwaters of another via unequal rates of erosion or uplift or when rearrangement of river deltas causes rivers to coalesce before they reach the ocean (Bishop 1995, Waters and Wallis 2000, Hughes et al. 2009). In the case of the Nicholson catchment, the Nicholson and Gregory rivers might have historically reached the Gulf/Lake Carpentaria independently, and populations in each would have been diverging in isolation. Then, after populations in each catchment had diverged, drainage rearrangements could have caused the rivers to merge before reaching the Gulf of Carpentaria, and restricted gene flow could have allowed each river to remain fixed for different haplotypes.

In another study of genetic structure in freshwater fish populations from this region, Masci et al. (2008) sampled mtDNA in Nematalosa erebi from the divergent KFC site. They found that the population at the KFC site was not deeply divergent from populations in other catchments in the Gulf of Carpentaria Basin. Population genetic studies on N. erebi suggest that it is a more proficient disperser than A. macleayi (Hughes and Hillyer 2006, Masci et al. 2008). Thus, the historical signature might have been lost because of recent gene flow. Alternatively, the result from the study by Masci et al. (2008) might have arisen from a rare, intercatchment dispersal event during an intermittent freshwater connection from a more divergent catchment west of the Nicholson catchment. This hypothesis has been proposed for a similarly confusing result for a freshwater crayfish, Cherax quadricarinatus, in this region (Baker et al. 2008).

Results from previous studies in the Gulf of Carpentaria Basin highlight the role of Lake Carpentaria in driving genetic structure in freshwater taxa (de Bruyn et al. 2004, Baker et al. 2008). In 3 studies of freshwater crustaceans (Macrobrachium rosenbergii, Macrobrachium australiensis, and C. quadricarinatus), mtDNA sequences showed shallow divergences among catchments, with many haplotypes shared between sites in distant catchments (de Bruyn et al. 2004, Baker et al. 2008, Masci et al. 2008). The same result also was found in 2 freshwater fishes (Neosilurus hyrtlii and N. erebi; Huey et al. 2008, Masci et al. 2008).

The results of these studies differ from ours in which genetic divergence among catchments was pronounced with no shared haplotypes and $2 \mathrm{bp}$ separating haplotypes in each catchment. In the only study to date divergences between catchments that historically flowed into Lake Carpentaria, Huey et al. (2008) estimated that most populations of N. hyrtlii in separate catchments began diverging before Lake Carpentaria became saline. Thus, despite showing shallow divergences between catchments, the taxa described above also might have begun to diverge before the lake became saline. Alternatively, the lake might have last become saline earlier than predicted by Chivas et al. (2001). For example, Unmack (2001) suggested that it is improbable that Lake Carpentaria provided an effective migration route within the last $10,000 \mathrm{y}$.

Overall, our study revealed high genetic structure among populations, both within and among catchments. This result has 2 important implications: 1) if populations of $A$. macleayi were to become locally extinct, many generations might be required for individuals from extant populations to recolonize extirpated regions; and 2) if $A$. macleayi were to be lost totally from a catchment, valuable and unique genetic divergence would be lost, and human intervention would be required for the species to recolonize the catchment.

\section{Acknowledgements}

We are thankful to all the people who assisted with field work, including James Fawcett, Tim Page, Ben Cook, Catherine Leigh, Erika Alacs, and Steve Smith. During these field trips, samples were collected under a Queensland General Fisheries Permit (PRM03315D) and collections adhered to Griffith University ethical guidelines (permit number AES/12/04). This research was funded by Griffith University and the Australian Rivers Institute. We thank Stephen Balcombe and anonymous referees for helpful comments on the manuscript.

\section{Literature Cited}

Amoros, C., And G. Bornette. 2002. Connectivity and biocomplexity in waterbodies of riverine floodplains. Freshwater Biology 47:761-776.

Avise, J. C. 2000. Phylogeography. The history and formation of species. Harvard University Press, Cambridge, Massachusetts.

BAKer, N., M. De BruYn, AND P. B. Mather. 2008. Patterns of molecular diversity in wild stocks of the redclaw crayfish (Cherax quadricarinatus) from northern Australia and Papua New Guinea: impacts of Plio-Pleistocene landscape evolution. Freshwater Biology 53:1592-1605.

Ballard, J. W. O., AND M. D. DEAN. 2001. The mitochondrial genome: mutation, selection and recombination. Current Opinion in Genetics and Development 11:667-672.

Ballard, J. W. O., And M. Kreitman. 1995. Is mitochondrial DNA a strictly neutral marker? Trends in Ecology and Evolution 10:485-488. 
Bishop, K. A., R. W. J. Pidgeon, and D. J. Walden. 1995. Studies on fish movement dynamics in a tropical floodplain river: prerequisites for a procedure to monitor the impacts of mining. Australian Journal of Ecology 20:81-107.

Bishor, P. 1995. Drainage rearrangement by river capture, beheading and diversion. Progress in Physical Geography 19:449-473.

Boileau, M. G., P. D. Herbert, and S. S. Schwartz. 1992. Nonequilibrium gene frequency divergence: persistent founder effects in natural populations. Journal of Evolutionary Biology 5:25-39.

Burridge, C. P., D. Craw, and J. M. Waters. 2006. River capture, range expansion, and cladogenesis: the genetic signature of freshwater vicariance. Evolution 60: 1038-1049.

Chivas, A. R., A. Garcia, S. van der Kaars, M. J. J. Couapel, S. Holt, J. M. Reeves, D. J. Wheeler, A. D. Switzer, C. V. Murray-Wallace, D. Banerjee, D. M. Price, S. X. Wang, G. Pearson, N. Terry Edgar, L. Beaufort, P. De DeckKer, E. Lawson, And C. Blaine Cecil. 2001. Sea-level and environmental changes since the last interglacial in the Gulf of Carpentaria, Australia: an overview. Quaternary International 83-85:19-46.

Clement, M., D. Posada, and K. A. Crandall. 2000. TCS: a computer program to estimate gene genealogies. Molecular Ecology 9:1657-1659.

CoOK, B. D., AND J. M. Hughes. 2010. Historical population connectivity and fragmentation in a tropical freshwater fish with a disjunct distribution (pennyfish, Denariusa bandata). Journal of the North American Benthological Society 29:1119-1131.

Cornuet, J. M., AND G. LuiKart. 1996. Description and power analysis of two tests for detecting recent population bottlenecks from allele frequency data. Genetics 144: 2001-2014.

De Bruyn, M., J. C. Wilson, And P. B. Mather. 2004. Reconciling geography and genealogy: phylogeography of giant freshwater prawns from the Lake Carpentaria region. Molecular Ecology 13:3515-3526.

De Woody, J. A., AND J. C. Avise. 2000. Microsatellite variation in marine, freshwater and anadromous fishes compared with other animals. Journal of Fish Biology 56:461-473.

Donaldson, K. A., AND R. R. Wilson. 1999. Amphi-Panamic geminates of Snook (Percoidei: Centropomidae) provide a calibration of the divergence rate in the mitochondrial DNA control region of fishes. Molecular Phylogenetics and Evolution 13:208-213.

Doyle, J. J., AND J. L. Doyle. 1987. A rapid DNA isolation procedure for small quantities of leaf tissues. Phytochemical Bulletin 19:11-15.

EFREMOV, V. V. 2004. The rate of approach to the equilibrium value of FST in island and one-dimensional stepping stone models of migration. Russian Journal of Genetics 40:1041-1045.

EMERSON, B. C. 2007. Alarm bells for the molecular clock? No support for Ho et al.'s model of time dependant molecular rate estimates. Systematic Biology 56:337-345.
Excoffier, L., G. LAVAL, AND S. SCHNEIDER. 2005. Arlequin ver. 3.0: an integrated software package for population genetics data analysis. Evolutionary Bioinformatics Online 1:47-50.

Excoffier, L., P. E. Smouse, AND J. M. Quattro. 1992. Analysis of molecular variance inferred from metric distances among DNA haplotypes: application to human mitochondrial DNA restriction data. Genetics 131:479-491.

Fu, Y. 1997. Statistical tests of neutrality of mutations against population growth, hitchhiking and background selection. Genetics 147:915-925.

Guo, S., And E. Thompson. 1992. Performing the exact test of Hardy-Weinberg proportion for multiple alleles. Biometrics 48:361-372.

Hey, J., And R. Nielsen. 2004. Multilocus methods for estimating population sizes, migration rates and divergence time, with applications to the divergence of Drosophila pseudoobscura and D. persimilis. Genetics 167: 747-760.

Hillyer, M. J., S. L. Boulter, R. L. Kitching, and J. M. Hughes. 2007. Isolation and characterization of eight polymorphic microsatellite loci in the rainforest canopy tree, Syzygium sayeri (Myrtaceae). Molecular Ecology Notes 7: 1199-1201.

Ho, S. Y. W., AND G. LARSON. 2006. Molecular clocks: when times are a-changin'. Trends in Genetics 22:79-83.

Ho, S. Y. W., M. J. Phillips, A. Cooper, And A. J. Drummond. 2005. Time dependency of molecular rate estimates and systematic overestimation of recent divergence times. Molecular Biology and Evolution 22:1561-1568.

Huey, J. A., A. M. BaKer, AND J. M. Hughes. 2008. The effect of landscape processes upon gene flow and genetic diversity in an Australian freshwater fish, Neosilurus hyrtlii. Freshwater Biology 53:1393-1408.

Huey, J. A., J. M. Hughes, And A. M. Baker. 2006. Patterns of gene flow in two species of eel-tailed catfish, Neosilurus hyrtlii and Porochilus argenteus (Siluriformes: Plotosidae), in western Queensland's dryland rivers. Biological Journal of the Linnaean Society 87:457-467.

Hughes, J. M. 2007. Constraints in recovery: using molecular methods to study connectivity of aquatic biota in rivers and streams. Freshwater Biology 52:616-631.

Hughes, J. M., AND M. J. Hillyer. 2006. Mitochondrial DNA and allozymes reveal high dispersal abilities and historical movement across drainage boundaries in two species of freshwater fishes from inland rivers in Queensland, Australia. Journal of Fish Biology 68: 270-291.

Hughes, J. M., M. Ponniah, D. Hurwood, S. Chenoweth, and A. Arthington. 1999. Strong genetic structuring in a habitat specialist, the Oxleyan Pygmy Perch Nannoperca oxleyana. Heredity 83:5-14.

Hughes, J. M., D. J. Schmidt, And D. J. Finn. 2009. Genes in streams: using DNA to understand the movement of freshwater fauna and their riverine habitat. BioScience 59:573-583.

IKeDA, M., M. NunOKaWA, AND N. TANiguchi. 2003. Lack of mitochondrial gene flow between populations of the endangered amphidromous fish Plecoglossus altivelis 
ryukyuensis inhabiting Amami-Oshima Island. Fisheries Science 69:1162-1168.

KENNARD, M. J. 1995. Factors influencing freshwater fish assemblages in floodplain lagoons of the Normanby River, Cape York Peninsula: a large tropical Australian river. MPhil Thesis, Griffith University, Brisbane, Australia.

Krieg, F., A. Triantafyllidis, AND R. GuYOmard. 2000. Mitochondrial DNA variation in European populations of Silurus glanis. Journal of Fish Biology 56:713-724.

Labbe, T. R., and K. D. Fausch. 2000. Dynamics of intermittent stream habitat regulate persistence of a threatened fish at multiple scales. Ecological Applications 10:1774-1791.

LAKE, P. S. 2003. Ecological effects of perturbation by drought in flowing waters. Freshwater Biology 48: 1161-1172.

Leclerc, E., Y. Mailhot, M. Mingelbier, and L. Bernatchez. 2008. The landscape genetics of yellow perch (Perca flavescens) in a large fluvial ecosystem. Molecular Ecology 17:1702-1717.

LEVENE, H. 1949. On a matching problem arising in genetics. Annals of Mathematical Statistics 20:91-94.

Luikart, G., F. W. Allendorf, J. Cornuet, and W. B. Sherwin. 1998. Distortion of allele frequency distributions provides a test for recent population bottlenecks. Journal of Heredity 89:238-247.

LuIKART, G., AND J. CORNUET. 1998. Empirical evaluation of a test for identifying recently bottlenecked populations from allele frequency data. Conservation Biology 12: 228-237.

Macaranas, J. M., P. B. Mather, P. Hoeben, and M. F. Capra. 1995. Assessment of genetic variation in wild populations of the redclaw crayfish (Cherax quadricarinatus, von Martens 1868) by means of allozyme and RAPD-PCR markers. Marine and Freshwater Research 46: 1217-1228.

Magoulick, D. D., AND R. M. KobZA. 2003. The role of refugia for fishes during drought: a review and synthesis. Freshwater Biology 48:1186-1198.

Masci, K. D., M. Ponniah, And J. M. Hughes. 2008. Patterns of connectivity between the Lake Eyre and Gulf of Carpentaria drainages: a phylogeographic approach. Marine and Freshwater Research 59:751-760.

Maynard Smith, J., AND J. Haigh. 1974. The hitchhiking effect of a favourable gene. Genetical Research 23:23-25.

McGlashan, D. J., AND J. M. Hughes. 2000. Reconciling patterns of genetic variation with stream structure, earth history and biology in the Australian freshwater fish Craterocephalus stercusmuscarum (Atherinidae). Molecular Ecology 9:1737-1751.

McGlashan, D. J., And J. M. Hughes. 2001. Genetic evidence for historical continuity between populations of the Australian freshwater fish Craterocephalus stercusmuscarum (Atherinidae) east and west of the Great Dividing Range. Journal of Fish Biology 59:55-67.

McGlashan, D. J., AND J. M. Hughes. 2002. Extensive genetic divergence among populations of the Australian freshwater fish, Pseudomugil signifer (Pseudomugilidae), at different hierarchical scales. Marine and Freshwater Research 53:897-907.

McGuigan, K., D. Zhu, G. R. Allen, and C. Moritz. 2000. Phylogenetic relationships and historical biogeography of melanotaeniid fishes in Australia and New Guinea. Marine and Freshwater Research 51:713-723.

Meffe, G. K., and R. C. VRijenhoek. 1988. Conservation genetics in the management of desert fishes. Conservation Biology 2:157-169.

Moran, P. 2002. Current conservation genetics: building an ecological approach to the synthesis of molecular and quantitative genetic methods. Ecology of Freshwater Fish 11:30-55.

Nei, M., T. Maruyama, and R. Chakraborty. 1975. The bottleneck effect and genetic variability in populations. Evolution 29:1-10.

Palumbi, S., A. Martin, S. Romano, W. O. McMillan, L. Stice, AND G. GrabowsKi. 1991. The simple fools guide to PCR, version 2. University of Hawaii, Honolulu, Hawaii.

Pereira, L. H. G., F. Foresti, and C. Oliveira. 2009. Genetic structure of the migratory catfish Pseudoplatystoma corruscans (Siluriformes: Pimelodidae) suggesting homing behaviour. Ecology of Freshwater Fish 18:215-225.

Perry, R. A. 1964. Summary description of the LeichhardtGilbert area. Pages 16-21 in R. A. Perry (editor). General report on lands of the Leichhardt-Gilbert area, Queensland. Commonwealth Scientific and Industrial Research Organisation, Melbourne, Australia. (Available from: http:/ / www.clw.csiro.au/publications/landresearchseries/ lrs11.pdf)

Perry, R. A., J. R. Sleeman, C. R. Twidale, and C. E. PRITCHARD. 1964. Land systems of the Leichhardt-Gilbert area. Pages 25-28 in R. A. Perry (editor). General report on lands of the Leichhardt-Gilbert area, Queensland. Commonwealth Scientific and Industrial Research Organisation, Melbourne, Australia. (Available from: http:/ / www.clw.csiro.au/publications/landresearchseries/lrs11. pdf)

Piry, S., G. LuikART, AND J. CoRnUet. 1999. BOTTLENECK: a computer program for detecting recent reductions in the effective population size using allele frequency data. Journal of Heredity 90:502-503.

Poissant, J., T. W. Knight, and M. M. Ferguson. 2005. Nonequilibrium conditions following landscape rearrangement: the relative contribution of past and current hydrological landscapes on the genetic structure of a stream-dwelling fish. Molecular Ecology 14:1321-1331.

Pusey, B. J., M. J. Kennard, And A. Arthington. 2004. Freshwater fishes of north-eastern Australia. CSIRO Publishing, Collingwood, Victoria, Australia.

Raymond, M., AND F. Rousset. 1995. GENEPOP (version 1.2): population genetics software for exact tests and ecumenicism. Journal of Heredity 86:248-249.

Reeves, J. M., A. R. Chivas, A. Garcia, And P. De DeckKer. 2007. Palaeoenvironmental change in the Gulf of Carpentaria (Australia) since the last interglacial based on Ostracoda. Palaeogeography, Palaeoclimatology, Palaeoecology 246:163-187. 
Reeves, J. M., A. R. Chivas, A. Garcia, S. Holt, A. J. J. Couapel, B. J. Jones, D. I. Cendón, And D. Fink. 2008. The sedimentary record of palaeoenvironments and sealevel change in the Gulf of Carpentaria, Australia, through the last glacial cycle. Quaternary International 183:3-22.

SLATKIN, M. 1993. Isolation by distance in equilibrium and non-equilibrium populations. Evolution 47:264-280.

SlAtKIN, M. 1995. A measure of population subdivision based on microsatellite allele frequencies. Genetics 139: 457-462.

So, N., J. K. J. van Houdt, and F. A. M. Volckaert. 2006. Genetic diversity and population history of the migratory catfishes Pangasianodon hypophthalmus and Pangasius bocourti in the Cambodian Mekong River. Fisheries Science 72:469-476.

Stepien, C. A., and J. E. Faber. 1998. Population genetic structure, phylogeography and spawning philopatry in walleye (Stizostedion vitreum) from mitochondrial DNA control region sequences. Molecular Ecology 7:1757-1769.

TAJIMA, F. 1989a. Statistical method for testing the neutral mutation hypothesis by DNA polymorphism. Genetics 123:585-595.

TAJIMA, F. 1989b. The effect of change in population size on DNA polymorphism. Genetics 123:597-601.

Takagi, A. P., S. Ishikawa, T. NaO, S. Hort, M. Nakatani, M. NishidA, AND H. KuROKURA. 2006. Genetic differentiation of the bronze featherback Notopterus notopterus between Mekong River and Tonle Sap Lake populations by mitochondrial DNA analysis. Fisheries Science 72: 750-754.

Torgersen, T., M. F. Hutchinson, D. E. Searle, and H. A. Nix. 1983. General bathymetry of the Gulf of Carpentaria and the Quaternary physiography of Lake Carpentaria. Palaeogeography, Palaeoclimatology, Palaeoecology 41: 207-225.

Torgersen, T., J. Luly, P. De DeckKer, M. R. Jones, D. E. Searle, A. R. Chivas, and W. J. Ullman. 1988. Late Quaternary environments of the Carpentaria Basin, Australia. Palaeogeography, Palaeoclimatology, Palaeoecology 67:245-261.

Twidale, C. R. 1964a. Geomorphology of the LeichhardtGilbert area. Pages 115-124 in R. A. Perry (editor). General report on lands of the Leichhardt-Gilbert area, Queensland. Commonwealth Scientific and Industrial Research Organisation, Melbourne, Australia. (Available from: http://www.clw.csiro.au/publications/landresearchseries/ lrs11.pdf)

Twidale, C. R. 1964b. Surface hydrology of the LeichhardtGilbert area. Pages 125-128 in R. A. Perry (editor). General report on lands of the Leichhardt-Gilbert area, Queensland. Commonwealth Scientific and Industrial Research Organisation, Melbourne, Australia. (Available from: http://www.clw.csiro.au/publications/ landresearchseries/lrs11.pdf)

UNMACK, P. J. 2001. Biogeography of Australian freshwater fishes. Journal of Biogeography 28:1053-1089.

van Oosterhout, C., W. F. Hutchinson, D. P. Wills, and P. SHIPLEY. 2004. MICRO-CHECKER: software for identifying and correcting genotyping errors in microsatellite data. Molecular Ecology Notes 4:535-538.

VorIS, H. K. 2000. Maps of Pleistocene sea levels in Southeast Asia: shorelines, river systems and time durations. Journal of Biogeography 27:1153-1167.

VRIJENHOEK, R. C. 1998. Conservation genetics for freshwater fish. Journal of Fish Biology 53:394-412.

WARD, R. D., M. WoOdWARK, AND D. O. F. SKIBINSKI. 1994. A comparison of genetic diversity levels in marine, freshwater, and anadromous fishes. Journal of Fish Biology 44:213-232.

Waters, J. M., AND G. P. Wallis. 2000. Across the Southern Alps by river capture? Freshwater fish phylogeography in South Island, New Zealand. Molecular Ecology 9: 1577-1582

Weir, B. S., AND C. C. Cockerham. 1984. Estimating Fstatistics for the analysis of population structure. Evolution 38:1358-1370.

WRIGHT, S. 1943. Isolation by distance. Genetics 28:114-138.

Zane, L., L. Bargelloni, and T. Patarnello. 2002. Strategies for microsatellite isolation: a review. Molecular Ecology 11:1-16. 